\title{
IDENTITAS “LAJANG” (SINGLE IDENTITY) DAN STIGMA: STUDI FENOMENOLOGI PEREMPUAN LAJANG DI SURABAYA
}

\author{
Ema Septiana dan Muhammad Syafiq \\ Program Studi Psikologi Universitas Negeri Surabaya
}

\begin{abstract}
This study was aimed to explore middle class single adult women's experience concerning their identity as a single in Surabaya. The number of single adult women in Surabaya has been increased since 2010 until recently. Phenomenological method was used in this study. Data collected using indepth semi-structured interviews and analysed using IPA (Interpretative Phenomenological Analysis). This study reveals three themes, namely the experience of being stigmatized, psychological impacts of the stigma, and strategies employed to cope with stigma and psychological discomforts. Most participants reported that they are called as "perawan tua" (spinster), "tidak laku”" (leftover) by social surroundings. They are also blamed as having negative traits such as introvert because of their single status. The experience of being stigmatized has impacted on their psychological discomforts such as insecure feelings and loneliness. To cope with stigma and psychological discomforts, most participants employed some strategies, namely reevaluating single identity in positive ways, avoiding situations wich invite stigma, and accepting God's destiny and plan.
\end{abstract}

Keywords: Single women, single identity threat, stigma.

\begin{abstract}
Abstrak: Penelitian ini bertujuan untuk mengetahui pengalaman perempuan lajang kelas menengah di Surabaya. Meningkatnya jumlah perempuan lajang di Surabaya dari tahun 2010 hingga tahun 2012 dan masih dijumpainya stigma negatif kepada perempuan lajang menjadi dasar dilakukannya penelitian ini. Metode yang digunakan adalah kualitatif fenomenologis dengan pengambilan data menggunakan wawancara semiterstruktur. Data yang telah diperoleh dianalisis menggunakan teknik analisis interpretative phenomenological analysis (IPA). Penelitian ini berhasil mengidentifikasi tiga tema utama, yaitu pengalaman terkait stigma terhadap identitas lajang; kondisi psikologis akibat stigma terhadap lajang, dan cara menghadapi tekanan dan stigma. Para partisipan melaporkan bahwa mereka dianggap dan diperbincangkan sebagai perawan tua, perempuan tidak laku, dan memiliki sifat tertutup yang tidak mendukung terjalinnya hubungan intim. Pengalaman stigma tersebut telah mempengaruhi kondisi psikologis sebagai perempuan lajang, yaitu perasaan tertekan dan kesepian. Dalam menghadapi tekanan akibat stigma dan upaya untuk mengatasi tekanan psikologis tersebut, para partisipan penelitian ini menempuh strategi untuk mempertahankan rasa identitas yang positif sebagai lajang, antara lain: memaknai kembali status lajang lebih positif, menghindari situasi yang menimbulkan stigma, dan menyerahkan diri pada takdir.
\end{abstract}

Kata kunci: Perempuan lajang, ancaman identitas lajang, stigma.

Fenomena hidup lajang (single) telah muncul dalam skala global. DePaulo (2008) memaparkan bahwa Biro Sensus Amerika Serikat mencatat pada tahun $2009,40 \%$ dari penduduk dewasa di Negara itu belum menikah. Sebelumnya, sensus pada tahun 2007 menunjukkan bahwa 12,3\% dari wanita umur 40an di Amerika hidup melajang. Berdasarkan sensus tahun 2006 di Australia, perempuan yang hidup lajang tanpa menikah 
mencapai 13,5\%.Jumlah perempuan dewasa yang tidak menikah di beberapa negara lain juga cukup signifikan antara lain: 5,1\% di Morocco, 6,0\% di Kuwait, 6,4\% di Israel dan $8,2 \%$ di Palestina (dalam DePaulo, 2008). Di Indonesia sendiri, hasil sensus penduduk tahun 2010 yang dilaporkan oleh Badan Pusat Statistik (BPS) menunjukkan bahwa perempuan berusia 30-54 yang belum menikah berjumlah $1,418,689$ orang atau sekitar $4,1 \%$ dari total jumlah perempuan Indonesia dalam rentang usia yang sama (BPS online, 2013). Fenomena peningkatan jumlah perempuan dewasa belum menikah juga terjadi di kota Surabaya. Berdasarkan data dari Dinas Kependudukan dan Catatan Sipil kota Surabaya bulan Oktober 2012, tercatat pada tahun 2010 jumlah wanita usia 30 tahun ke atas yang masih lajang sebesar 103.568 penduduk, meningkat menjadi 106.771 pada tahun 2011 dan 108.695 pada tahun 2012.

Pada umumnya perempuan dewasa awal yang menunda pernikahan terhalang karena belum menemukan pasangan yang tepat, namun ada juga yang hidup melajang karena merupakan pilihan. Seperti yang diungkapkan oleh Feldman (2009), beberapa orang ingin tetap menikmati kebebasan dalam mengambil resiko, bereksperimen, berkeliling dunia, mengejar karir, melanjutkan pendidikan, atau melakukan pekerjaan kreatif. Hurlock (1980) menjelaskan bahwa selama usia dua puluhan, tujuan dari sebagian besar perempuan yang belum menikah adalah perkawinan. Apabila seorang perempuan belum juga menikah pada waktu berumur 30 tahun, mereka cenderung mengganti tujuan dan nilai hidupnya ke arah nilai dan tujuan yang baru dan berorientasi pada pekerjaan, karir, dan kesenangan pribadi. Hurlock (1980) menyimpulkan bahwa perempuan yang belum menikah stelah memasuki usia 30-an akan memasuki fase usia kritis (critical age) karena mereka berada dalam persimpangan anatara pilihan tetap ingin menikah atau akan bertahan menjadi lajang.

Namun, kehidupan lajang bagi perempuan bukanlah situasi yang bebas dari tekanan masyarakat dominan. Masyarakat Amerika, yang dalam kajian psikologi lintas budaya dianggap lebih berorientasi individualis (Markus \& Kitayama, 1991; Matsumoto, 2004), hingga saat ini begitu menghargai pernikahan dan pasangan yang menikah (DePaulo \& Morris, 2005, 2006). Masyarakat Indonesia adalah bagian dari masyarakat Asia yang digambarkan oleh beberapa ahli (Markus \& Kitayama, 1991; Matsumoto, 2004) memiliki kecenderungan kolektivis yang lebih kental dibanding masyarakat Amerika dan Eropa. Karena itu anggota masyarakat Indonesia tentunya mengalami tekanan jauh lebih kuat untuk memegang norma budayanya, termasuk pernikahan. Pernikahan adalah salah satu ritus budaya yang sangat dihargai oleh hampir semua kelompok etnis dan budaya di Indonesia dan setiap orang diharapkan untuk memasuki pernikahan pada usia dewasanya. Orang dewasa yang belum menikah dan tinggal dalam budaya yang mengharapkan perempuan menikah, mereka akan mendapatkan tekanan dari orangtua dan teman-temannnya untuk segera menikah (Hurlock, 1980).

Dalam perspektif gender, tuntutan menikah jauh lebih berat pada perempuan dewasa dari pada laki-laki. Kecenderungan budaya patriarkis pada masyarkat Indonesia telah membuat perempuan didorong untuk menjadi ibu dan istri dalam sebuah keluarga agar ia dihargai sebagai anggota mayarakat sepenuhnya. Karena budaya tersebut, setiap keluarga akan tetap menyarankan anak perempuannya untuk menikah (Kumalasari, 2007). Perempuan yang belum menikah oleh masyarakat Jawa sebagai belum sepenuhnya dapat dianggap perempuan yang lengkap (Mulder, dalam Hapsari dkk., 2007). Penelitian Kumalasari (2007) terhadap 10 
single professional woman (SPW) berusia 3050 tahun di Sleman, Yogyakarta, berhasil mengungkap bahwa mereka cenderung dipandang masyarakat bukan sebagai perempuan dengan profesi tertentu, tapi sebagai perempuan yang belum menikah. Para partisipan penelitian tersebut berprofesi sebagai pengusaha, guru, dosen, dan pengacara. Keluarga dan teman kerja mereka lebih cenderung menyoroti status tidak menikah mereka dan menyarankan agar segera menikah daripada mendukung pekerjaan profesional mereka. Akhirnya, pertanyaan yang dianggap menekan dan mencampuri urusan pribadi dari keluarga dan masyarakat seperti "kapan menikah?" kerap ditujukan kepada perempuan dewasa yang masih lajang (Indriana dkk., 2007).

Perempuan lajang telah menjadi sebuah kategori sosial tersendiri yang dilekati dengan karakteristik yang khas yang seringkali bernada negatif atau "tidak normal" karena akan cenderung dibandingkan dengan kelompok perempuan yang sudah menikah yang lebih dipandang "normal". Pengkategorian dan perbandingan inilah yang akhirnya memunculkan suatu karakteristik identitas yang khas pada perempuan lajang. Teori Identitas Sosial dari Tajfel \& Turner (1979) menjelaskan bahwa pengkategorisasian sosial merupakan hasil alamiah dari proses kategorisasi kognitif yang dilakukan setiap individu. Pengkategorian ini terbentuk berdasarkan kesamaan dan perbedaan karakteristik setiap individu yang ada dalam atau di luar kelompok kategori. Berdasarkan perspektif ini, kita bisa mengasumsikan bahwa meskipun memiliki motivasi dan prestasi yang berbeda-beda, semua perempuan yang melajang pada usia dewasa akan cenderung dipandang sama dalam konteks hubungan sosial, yaitu "belum menikah".

Adanya kategorisasi sosial tersebut akan diiringi dengan munculnya nilai-nilai psikologis yang berdampak pada harga diri setiap individu yang masuk dalam kategori tersebut. Jika status suatu kelompok individu dipandang negatif, maka para anggotanya akan mendapatkan evaluasi negatif dan pada akhirnya akan berdampak pada turunnya harga diri mereka (Burke dan Stets, 2000). Dalam hal kategori status pernikahan, status belum menikah pada perempuan dewasa akan cenderung diposisikan sebagai status identitas yang bersifat negatif atau inferior karena status tersebut cenderung dianggap tidak sesuai dengan kewajaran atau "tidak normal".

Teori Identitas Sosial meramalkan bahwa individu yang berada dalam suatu kategori sosial dengan status identitas negatif akan cenderung merasakan ancaman identitas (identity threat). Ancaman identitas sosial merupakan bentuk dari perasaan individu yang merasa dirinya akan mendapatkan evaluasi negatif jika status identitasnya yang telah dinilai negatif terungkap. Ancaman identitas sosial ini mengakibatkan timbulnya kekhawatiran individu tentang diri mereka sendiri dalam sebuah hubungan sosial (Derks, Inzlicht, \& Kang, 2008). Alasan mengapa ancaman identitas bisa muncul adalah karena menurut Teori Identitas Sosial (dalam Korf \& Malan, 2002), setiap individu akan cenderung berupaya untuk mendapatkan dan menjaga harga diri yang positif melalui keanggotaannya dalam sebuah kelompok atau kategori sosial. Jika persepsi positif seseorang terhadap identitas sosialnya ditantang oleh pandangan negatif banyak orang, individu tersebut akan mengalami rasa terancam, dan sebagai akibatnya akan muncul emosi negatif (Walton \& Cohen, 2007).

Berdasarkan perspektif ini dapat diasumsikan bahwa perempuan dewasa yang memiliki status identitas "lajang" (single) akan mengalami ancaman karena identitas tersebut. Ancaman itu bersumber dari evaluasi negatif atau stereotip masyarakat atas status "lajang". Stereotip atau bentuk-bentuk penilaian negatif terhadap status "lajang" 
inilah yang akhirnya membuat perempuan dengan status tersebut rentan menjadi target stigma. Stigma adalah semua bentuk kualitas bersifat fisik, sosial, atau personal yang membuat kelompok orang yang memilikinya dilabeli dengan identitas yang mendiskreditkan dan inferior (Goffman, 1963). Dalam pengertian ini, kualitas status sosial "lajang" akan membuat para perempuan lajang mendapatkan label yang mendiskreditkan dan merendahkan. Penelitian Indriana dkk., (2007) misalnya melaporkan perempuan dewasa lajang di Jawa yang menjadi partisipan mereka dianggap sebagai tertutup, emosional, kekanak-kanakan, dan mudah marah.

Bahkan pada masayarakat individualis seperti di Amerika, orang-orang yang hidup melajang juga cenderung menjadi target stigma (DePaulo \& Morris, 2005, 2006; Byrne \& Carr, 2005). Penelitian Greitemeyer (2009) juga mengungkapkan bahwa masyarakat Jerman menunjukkan sikap negatif terhadap orang yang melajang (single). Secara umum, perempuan dewasa lajang cenderung mendapatkan beberapa stereotip seperti: kurang dapat mengemban tanggungjawab, kurang dewasa, dan kurang bisa bergaul daripada mereka yang telah menikah (Etaugh \&Birdoes, 1991; Conley \& Collins, 2002). Kajian literatur dalam bidang psikologi perkembangan juga menunjukkan bahwa perempuan dewasa yang tidak atau belum menikah (singles) sering diposisikan sebagai "berbeda", bermasalah dalam menjalin hubungan intim, atau bahkan memiliki "disfungsi" pribadi hingga perlu mendapatkan intervensi terapeutik (Reynolds \& Wetherell, 2003; Reynolds, 2002)

Namun, berdasarkan perspektif Model Ancaman Identitas (Major dan O'Brien, 2004), individu atau kelompok sosial yang menjadi target stigma berpeluang untuk melawan stigma melalui dua strategi umum, yaitu cara vokasional dan nonvokasional.
Cara vokasional adalah cara yang melibatkan usaha untuk menyelesaikan, sedangkan cara nonvokasional adalah cara tidak melibatkan usaha untuk menyelesaikan termasuk didalamnya adalah menyembunyikan status yang mendatangkan stigma atau menghindar dari situasi yang mendatangkan stigma.

Berdasarkan latarbelakang di atas, penelitian ini bertujuan untuk mengungkap pengalaman hidup perempuan dewasa lajang kelas menengah di Surabaya terkait dengan identitas sosial "lajang" yang mereka sandang. Penelitian ini mengeksplorasi bagaimana perempuan lajang mempersepsi status lajang mereka sebagai respon atas pandangan masyarakat dan dampak psikologis yang mereka dirasakan. Penelitian ini juga berupaya untuk mengungkap bagaimana pengalaman stigma yang didapatkan, dan cara mereka menghadapi stigma tersebut.

\section{METODE}

Penelitian ini menggunakan metode kualitatif fenomenologis, yaitu jenis penelitian kualitatif yang melihat secara dekat bagaimana individu memaknai pengalamanpengalamannya sendiri (Emzir, 2010).

\section{Partisipan}

Partisipan penelitian ini berjumlah 6 (enam) orang yang direkrut melalui teknik purposive sampling dengan kriteria perempuan lajang belum pernah menikah, usia di atas 30-55 tahun dan memiliki penghasilan sendiri. Para partisipan tersebut adalah (dalam nama samaran): Marina (38 tahun) bekerja sebagai Pegawai Negeri Sipil dengan gaji 3 juta per bulan; Nisa (52 tahun) bekerja sebagai Pegawai Negeri Sipil dengan gaji 4 juta per bulan; Elisabeth (43 tahun) berwirausaha dengan rata-rata penghasilan sebesar 8 juta per bulan; Rina (42 tahun), seorang wirausahawan 
dan pengajar dengan rata-rata penghasilan 8 juta per bulan; Ira (50 tahun) bekerja sebagai staff Administrasi di Perusahaan swasta dengan gaji 2 juta per bulan; dan terakhir, Eki (37 tahun) bekerja sebagai guru privat dengan gaji 2 juta per bulan.

\section{Teknik Pengumpulan Data}

Teknik pengumpulan data yang digunakan dalam penelitian ini adalah wawancara semi-terstruktur dengan menggunakan pedoman wawancara yang tidak diikuti secara ketat. Pedoman wawancara berisi tiga pokok bahasan yakni pertanyaan demografis tentang data diri, pertanyaan mengenai pengalaman hidup melajang terkait stigma, makna terhadap atas status "lajang", dampak status tersebut terhadap diri mereka, dan cara-cara yang ditempuh untuk mengatasi tekanan dan stigma. Alat pengumpul data yang digunakan adalah alat perekam dan buku catatan. Proses wawancara diawali sebelumnya dengan membangum rapport pada semua partisipan selama kurun waktu sekitar satu bulan. Proses wawancara pada semua partisipan dilakukan dalam satu kali pertemuan yang berkisar antara 45 menit hingga 120 menit tanpa kehadiran pihak ketiga.

\section{Teknik Analisis Data}

Data yang diperoleh dianalisis menggunakan interpretative phenomenological analysis (IPA). Langkah-langkah analisis data yang dilakukan mengacu pada usulan Smith \& Osborn (2009), yaitu: pertama, mentranskrip seluruh data hasil wawancara berupa verbatim. Kemudian peneliti melakukan pengkodean dengan cara memberikan komentar pada masing-masing transkrip dan dituliskan di Margin sebelah kiri. Langkah berikutnya, komentar-komentar awal di marjin kiri tiap transkrip dibaca ulang untuk mendapatkan label-label yang lebih konseptual. Label-label konseptual di marjin kanan pada semua transkrip kemudian dikelompokkan berdasarkan kesamaan maknanya dan tiap kelompok ini diberi nama subtema. Seluruh subtema dikelompokkan kembali berdasarkan kedekatan cakupan maknanya dan diberi nama tema utama (superordinate themes). Seluruh proses pengkodingan ini bermuara pada hasil akhir berupa tebal tema hasil penelitian. Tabel tema inilah yang menjadi dasar penulisan laporan. Sebagai upaya untuk menjamin transparansi penelitian, peneliti mengutip ekstrak-ekstrak dari data asli dalam paparan hasil penelitian agar pembaca dapat menilai interpretasi dari peneliti. Teknik ini disebut grounding in example (Elliot dkk., 1999). Pada ekstrak wawancara peneliti menggunakan tanda "[...]" untuk menunjukkan ada bagian kecil dari data asli yang dihapus untuk tujuan memperlancar maksud partisipan. Sedangkan kata atau kalimat dalam tanda "( )" dalam ekstrak kutipan merupakan klarifikasi makna peneliti atas maksud partisipan.

\section{HASIL PENELITIAN}

Penelitian ini berhasil mengungkap tiga tema utama, yaitu pengalaman terkait stigma terhadap status lajang, dampak psikologis terkait dengan stigma, dan cara menghadapi stigma dan dampaknya.

\section{Tema : Pengalaman terkait stigma terhadap status lajang}

Beragam pengalaman sebagai target stigma dilaporkan oleh para partisipan. Nisa (52 th) misalnya melaporkan bahwa ia dianggap terlalu menutup diri terkait dengan statusnya yang masih lajang.

\footnotetext{
"Saya tahu biasanya orang selalu berfikir negatif ya. [...] dianggap aku itu masih menutup diri. [...] sampai sekarang pun aku tidak pernah menutup diri” (Nisa-B176.)
} 
Nisa menunjukkan melalui ekstrak di atas bahwa status lajangnya dipandang orangorang di sekitarnya sebagai sebuah kesalahan akibat ketidakmampuan pribadinya dalam berhubungan sosial. Ia menolak anggapan yang menyudutkan dirinya tersebut. Ia juga pernah mendengar ia dijuluki sebagai perawan tua yang tidak laku.

"Ya itu sih katanya gini, ah perawan tua, gak laku (tidak laku), gitu” (Nisa-B182)

Hal senada dialami oleh Eki (37 th) yang pernah mendengar ia diperbincangkan sebagai perempuan yang tidak laku karena belum menikah.

"[...] ya ada omongan (pembicaraan tentang saya), gak rabi-rabi (tidak kunjung nikah), gakpayu (tidak laku)," (Eki-B50)

Bahkan karena statusnya tersebut ia sampai dituduh merebut suami tetangganya.

"Mbak Lia (nama tetangganya) iku (itu), kemarin juga sempat jarene (katanya) aku mau merebut kono (suaminya)"(Eki-B68)

Kutipan wawancara Eki di atas menunjukkan bahwa ia mendapatkan tanggapan negatif dari perempuan lain yang telah menikah karena status lajangnya dipersepsi sebagai ancaman terhadap keutuhan rumah tangga. Artinya, status lajang Eki, dipersepsi perempuan berkeluarga di sekitarnya sebagai "godaan" bagi suami mereka.

Rina (42 th) juga merasakan bagaimana orang di sekitarnya memandang perempuan lajang seperti dirinya dalam cara yang merendahkan.

\footnotetext{
“Ada orang yang ngomong gini, cewek itu kalau masih muda, jual mahal, nanti kalau sudah tua jual murah, katanya. Kan ada orang prinsipnya itu gitu, maksudnya ada yang seperti itu, dari teman-teman saya (sesama lajang) itu kita kayak menurunkan standar gitu lho, dan (omongan) itu
}

salah satu pendorong teman teman saya cepat menikah gitu lho, karena ada orang ngomong gini, "Oh ini mumpung ada orang yang nyenengin saya, oh nikah aja, langsung nikah"." (Rina-B450)

"ada masanya wanita itu harus menikah, kalau ndak ini kita terlambat, kalau sudah melewati batas ini kita sudah nggak laku, ada orang yang ada di batas batas itu, kayak kesannya jadi jual murah, kesannya seperti itu." (Rina-B.460)

Kedua ekstrak wawancara di atas menunjukkan betapa status lajang pada perempuan dewasa membuat mereka dinilai sebagai "sudah lewat masanya" hingga "tidak laku". Karena itu, perempuan dewasa lajang dituntut untuk "menurunkan standarnya" agar dapat menikah. Rina mempersepsi seperti itulah cara pandang masyarakat terhadapnya dan para perempuan dewasa lajang lainnya. Rina juga menunjukkan ketidaknyamanannya terhadap perempuan dewasa lajang seperti dirinya yang terburu-buru memutuskan menikah hanya karena takut dengan tanggapan negatif orang disekitarnya.

\section{Tema: Kondisi Psikologis terkait stigma}

Pengalaman mendapatkan stigma dari masyarakat membuat para perempuan dewasa lajang yang menjadi partisipan dalam penelitian ini mengalami tekanan psikologis tertentu.

\section{Merasa tertekan}

Status perempuan dewasa lajang yang mengundang stigma membuat keluarga dan teman-teman para partisipan penelitian ini turut berupaya mendorong para partisipan agar segera menikah. Namun, perhatian yang terlalu berlebihan terhadap status lajang dari keluarga da teman-teman dekat ini dianggap para partisipan sebagai tekanan yang tidak menyenangkan. Keluarga Rina misalnya memberi tekanan dengan selalu bertanya "kapan menikah?" 
““'Ayo kapan kamu menikah?” [...] orangtua saya itu ngomong itu dan mereka mendesaknya kan sangat (sekali) gitu ya, mereka juga katanya malu [...] anaknya itu ndak anu (tidak menikah)"(Rina-B437)

Ekstrak wawancara di atas juga menunjukkan bahwa status lajang Rina dianggap keluarganya bukanlah urusan pribadi Rina belaka, tapi juga urusan keluarga. Bahkan status lajang Rina dirasakan oleh orang tuanya sebagai "membuat malu" keluarga.

Marina juga merasakan bagaimana keluarganya mengharapkannya agar segera memiliki pasangan.

"keluarga sih tetap berharap biar aku cepet punya pasangan.” (Marina-B220)

Marina menceritakan bagaimana dirinya merasa tertekan atas desakan untuk segera menikah tersebut. Marina menceritakan ada salah satu temannya yang ikut campur dalam urusannya mencari pasangan.

“Orangnya pengen ngurus-ngurus (ikut campur) gitu, aku jadi merasa risih, karena itu kan masalah pribadi ya. [...] aku nggak suka" (Marina-B178)

"[...] kalo memang belum ini (siap) masak harus dipaksa-paksakan, kalau seperti itu kan otomatis orangnya memaksa"(Marina-B196)

Marina merasa tidak nyaman karena tidak seharusnya masalah pribadi diurusi oleh orang lain apalagi dengan cara memaksa.

\section{Tidak nyaman}

Tekanan dari masyarakat terutama paling jelas muncul ketika para partisipan menghadiri perayaan-perayaan tertentu seperti acara pernikahan, kelahiran, arisan, dan bahkan acara reuni. Nisa tidak berani datang sendiri untuk menghadiri undangan pernikahan temannya. Ia lebih memilih tidak datang jika tidak ada yang menemaninya.

"Saya sulit itu kalau dapat undangan manten (pernikahan), itu sulit [...]. Siapapun yang mengundang, saya datang, kalau datang sendirian itu belum bisa"(Nisa-B289)

Elisabeth (43 th) merasakan bagaimana tidak nyamannya saat ia datang ke acara reuni.

“...] kalau ada acara reuni teman sekolah,
lha itu rasanya nggak enak banget (sangat
tidak nyaman), [...] semua orang tanya, dan
sebagainya, aduh rasanya pusing banget gitu
lho. [...] nggak enaknya kan buanyak (banyak
sekali), rasanya itu kita mbayangkan kayak
teror gitu.”(Elisabeth-B102)

Ia mendapatkan banyak pertanyaan seputar mengapa ia belum menikah. Ia menggambarkan rasa tidak nyamannya seperti sedang diteror. Hal yang sama diungkapkan oleh Ira (50 th), ia merasa tidak nyaman saat menghadiri pesta pernikahan.

"Nggak enak, ditanyain orang-orang. Kalau kita
menghadiri pernikahan, terus kalau lama gak
ketemu, nggak pake nanya sudah nikah apa
belum, tapi (langsung) tanya "anakmu
berapa?"(Ira-B150)

Hidup menjadi perempuan lajang dengan banyak stigma negatif tersebut, ternyata membuat hidup partisipan menjadi sulit. Hubungan dengan lawan jenis rawan dianggap sebagai kesalahan. Ira menceritakan pengalamannya.

"Kalau waktu pulang kerja, kadang-kadang
ketemu tetangga, waktu pulang dibarengi
(diantar pulang laki-laki) itu ndak enak juga
(perasaan tidak enak).”(Ira-B163)

Rasa tidak nyaman Ira ketika diketahui tetangganya pulang diantar laki-laki menunjukkan bahwa Ira telah menyadari bahwa status lajangnya bisa mengundang respon negatif. Kutipan ekstrak wawancara 
dengan Ira di atas juga menunjukkan bahwa Ira memiliki ketakutan bahwa ia akan dipandang rendah oleh masyarakat sekitar jika bergaul dengan laki-laki.

\section{Kesepian}

Berbagai tekanan yang dialami partisipan dari masyarakat sekitarnya memunculkan kesadaran bahwa hidup mereka tampak "kurang lengkap" jika belum berkeluarga. Karena itu, ada saat-saat tertentu dalam kehidupan para partisipan ketika mereka mengidamkan memiliki pasangan atau berkeluarga seperti perempuan lain pada umumnya. Elisabeth melaporkan pengalamannnya berikut:

"Kadang-kadang ada saat-saatnya, saya itu [...] pingin menikah, saya masih menghilangkan keinginan itu sepenuhnya ya gak bisa (tidak bisa), karena saya ga (tidak) berniat (melajang)." (Elisabeth-B396)

Keinginan menikah juga dirasakan oleh Marina (38 th) saat melihat seorang teman yang lebih muda telah memiliki anak.

"Iri juga, apalagi udah punya anak, masih muda kok sudah punya anak,"(Marina-B150)

\section{Nisa pun mengutarakan perasaannya.}

“...aku ngelihat gitu ya iri, aduh kok isok yo (kok bisa ya masih muda sudah berkeluarga?) [...] heh, aku iri. Yo wes akhire gak popo (ya sudah, tapi akhirnya sekarang tidak masalah)"(Nisa-B184)

Rasa iri ingin memiliki pasangan juga muncul pada Eki saat ada sepasang suami istri menunjukan kebersamaan di depannya.

\footnotetext{
"(saya) kondangan (pergi ke acara undangan) sendirian, situ (teman partisipan) berdua (dengan suaminya), dibonceng. Sakit (bisa) ngeluh, "aduuuh", lain kalau aku (lain jika saya). Sebelahku (teman partisipan) bojone seng ngelayani (suaminya yang melayaninya),
}

"opo dek" (ada apa dek [dek adalah panggilan untuk istri]/ada yang bisa dibantu dek?)"." (EkiB176)

Eki merasa iri karena tidak memiliki pasangan yang dapat menemaninya dan mengantarkannya kemanapun dan dapat memberinya perhatian seperti tetangganya yang berkeluarga. Rina juga menunjukkan situasi ketika ia berpikir membutuhkan pria sebagai pasangan hidup.

Misalnya gini (begini) ya kalau di rumah Sidoarjo dulu, ada masalah dengan lampu mati, [...] dengan Sanyo (pompa air), saya sampai mikir, ini ternyata susah kalau nggak ada cowok (laki-laki) di rumah, [...] ketika kita ketemu masalah-masalah seperti itu, kita tuh [...] baru menyadari bahwa sebenernya (sebenarnya) kita itu butuh [...]. " Seandainya ada pasangan" (Rina-B251)

Hal yang sama dirasakan oleh Elisabeth

\begin{abstract}
"Dukanya kalau ada hal-hal yang rasanya butuh tenaga pria, hahahaha, kalo pergi keluar kota kemalaman, rasanya apa, takut. Seandanya ada (suami), tapi kali sudah habis nglewatin (melalui situasi itu) ya sudah. hhahahaha". (Elisabeth-B295)
\end{abstract}

Elisabeth merasa membutuhkan pasangan hidup pada situasi yang menyulitkan. Namun, jika situasi itu sudah dilalui, perasaan membutuhkan itu hilang. Ketika mengungkapkan hal itu, Elisabeth tampak tertawa. Hal ini menunjukkan Elisabeth tidak terlalu memandang penting keinginannya untuk mendapatkan pasangan tersebut.

\section{Tema: Cara mengatasi stigma dan dampak psikologisnya}

Dalam menghadapi stigma dan tekanan psikologis akibat stigma, para partisipan penelitian ini menempuh strategi untuk mempertahankan rasa identitas yang positif 
sebagai lajang, antara lain: memaknai kembali status lajang lebih positif, menghindari situasi yang menimbulkan stigma, dan menyerahkan diri pada takdir.

\section{Memaknai kembali kelajangan secara positif}

Beratnya menanggung stigma yang telah melekat kepada perempuan lajang dapat memunculkan perasaan tidak puas terhadap diri sendiri dan kemampuan yang mereka miliki. Para partisipan penelitian ini berupaya untuk melawan stigma dengan memaknai kembali status lajangnya secara positif. Nisa menyatakan berikut:

"[...] Kalau sebagai orang bujang (lajang) sih, aku merasa sudah menjadi orang yang sempurna, hahahah" (Nisa-B460)

Dengan menyatakan "aku sudah merasa sebagai orang yang sempurna" sambil tertawa, Nisa tampaknya menyadari bahwa ucapannya tersebut hanyalah menunjukkan upayanya untuk menerima statusnya lajangnya sebagai sesuatu yang tidak bermasalah. Ia berusaha untuk menerima dirinya sebagai seseorang yang telah lengkap dan tidak tergantung pada harapannya untuk mendapatkan pasangan. Hal yang sama dirasakan oleh Marina, ia bersyukur dengan keadaan dirinya saat ini. Ia merasa status lajangnya tidak membuat dirinya merasa kekuarangan.

\footnotetext{
"Aku sih selalu beryukur, aku ya wis (sudah) bersyukur, nggak merasa kekurangan" (MarinaB10)
}

Saat partisipan mensyukuri keadaan diri mereka, dan tidak mempermasalahkannya. Besar kemungkinan mereka untuk menikmati kelajangan. Melakukan apa yang mereka ingin lakukan dan tidak merasa terbebani dengan kesendiriannya. Seperti yang dilaporkan oleh salah satu partisipan berikut:

\begin{abstract}
"Sebetulnya saya nggak (tidak) masalah tuh (dengan status lajang saya). Saya merasanya enjoy aja (menikmati)"(Nisa-B129)
\end{abstract}

Nisa mengaku menikmati status lajangnya. Ia memaknai kelajangan sebagai bebas dari beban pekerjaan rumah tangga.

\begin{abstract}
"Kalo gini (lajang) kan mau apa-apa itu bebas, baru (pulang) kerja capek langsung ngglundung (istirahat) bah (walaupun) sana berantakan sini berantakan. Tapi kalo ada keluarga kan pasti, teko omah jek ngrinkesi omah (sampai rumah harus masih membersihkan rumah)." (NisaB331)
\end{abstract}

Kebebasan dalam bentuk lain dirasakan oleh Marina. Status lajang dimaknai oleh Marina sebagai bebas melakukan apapun tanpa harus terikat oleh keinginan suami.

\begin{abstract}
"Enaknya itu kita kan nggak terikat gitu ya, misalnya pengen apa harus ngomong dulu (sama suami), misalkan mau kemana harus pamitan, aku mau ini ngomong dulu boleh apa nggak(tidak),"'(Marina-B66)
\end{abstract}

Ira juga merasa status lajangnya membuatnya tidak ada beban karena merasa tidak ada yang keberatan untuk ditinggalkan olehnya.

\footnotetext{
"Ya bisa pergi, pergi ke teman-teman, ngga ada beban, kalau mau pergi keluar kota, menjenguk teman, mau kemping ke (Gunung) Bromo." (Ira-B138)
}

Status lajang adalah peluang bagi para partisipan untuk bebas melakukan keinginnya sendiri. Status lajang juga dimaknai sebagai kemampuan untuk mengurus kehidupan sendiri atau mandiri. Elisabeth menyatakan berikut:

\footnotetext{
"Walaupun sendiri tapi saya bisa mengatasi kehidupan saya, [...] ternyata dengan kesendirian saya, saya masih [...] bisa berdiri." (Elisabeth-B136)
}

Rasa memiliki kemandirian pada para partisipan telah memberi mereka harga diri 
dan kebanggaan pada diri mereka sebagai perempuan lajang.

\section{Menghindari stigma}

Marina menanggapi orang yang terlalu mencampuri urusan pribadinya terkait status lajangnya dengan menjaga jarak.

"Aku cuma pengen (ingin) menjauh dari orang seperti itu, menghindari aja, nggak menjauh tapi menghindari, menjaga jarak.”(Marina-B201)

Nisa lebih memilih untuk tidak menghadiri undangan teman ke acara pesta atau perayaan kalau tidak ada orang yang menemaninya.

"Kalo nggak ada (teman) yang barengin (ke acara undangan), saya ijin nggak datang, "Sorry ya aku ngga datang"'. (Nisa-B302)

Nisa telah mengantisipasi bahwa datang ke acara semacam itu akan membuatnya mendapat perhatian yang terlalu berlebihan dan mengganggu terkait status lajangnya. Pengalaman serupa dilaporkan oleh Elisabeth.

\begin{abstract}
"Karena kita sudah tahu ya, nanti dateng ke acara itu, pasti yang ditanya pertanyaannya 'kamu dah (sudah) nikah belum, kamu udah (sudah) punya anak belum?' jadi saya males (malas) dan ya terus terang saya menghindari itu, [...] Berapa kali sih ada [...] reuni SMA pernah, tapi saya juga ngga dateng (tidak datang)." (Elisabeth-B104)
\end{abstract}

Ia enggan datang ke acara reuni karena pengalaman sebelumnya ia mendapat banyak pertyanyaan mengganggu seputar statusnya sebagai lajang.

\section{Menyerahkan diri pada takdir}

Semua partisipan melaporkan bahwa status lajang mereka tidak sepenuhnya keinginan pribadi. Mereka juga cenderung memposisikan status lajang mereka sebagai takdir Tuhan yang hanya bisa dijalani. "Hidup kok bisa melajang ini aku juga nggak
(tidak) tahu, [...] hidup saya itu sudah menurut
tuntunan Tuhan" (Nisa-B143)

\footnotetext{
"Kan ada prinsip kita lahir, nikah, mati kan rahasia Tuhan, rahasia Tuhan yang kita nggak bisa tahu. Ya jangan kita didesak (untuk menikah)."(Nisa-B179)
}

Nisa menegaskan bahwa ia tidak menginginkan dirinya terus menjadi lajang. Namun ia memposisikan status lajangnya sebagai takdir Tuhan yang harus ia jalani, entah sampai kapan.

"Saya belum memutuskan untuk hidup melajang, belum. Cuma saya menjalani hidup ini apa adanya seperti ini dijalani." (Rina-B271)

Ira pun tidak jauh berbeda, walaupun ia menikmati semua yang Tuhan rencanakan untuk dirinya, namun ia masih berharap menikah.

\footnotetext{
"Siapa sih yang nggak (tidak) pingin (ingin) menikah, terlepas dari itu kan rahasia Tuhan jadi ya dinikmati aja"(Ira-B65)
}

Meskipun sebagian besar partisipan tetap optimis Tuhan akan memberikan jodoh bagi mereka, namun mereka telah bersiap jika hidup melajang merupakan takdir yang sesungguhnya.

\section{PEMBAHASAN}

Teori Identitas Sosial meramalkan bahwa individu yang berada dalam kelompok dengan status identitas negatif atau inferior akan merasakan ancaman identitas (Derks, Inzlicht, \& Kang, 2008). Status identitas lajang (single identity) adalah salah satu bentuk identitas sosial berdasarkan status perkawinan yang diposisikan lebih inferior daripada status menikah (marital identity). 
Penelitian ini menunjukkan hasil yang sejalan dengan penelitian sebelumnya di Indonesia (Noviana \& Suci, 2010; Kumalasari, 2007; Indriana dkk., 2007), Amerika Serikat (DePaulo \& Morris, 2005, 2006; Byrne \& Carr, 2005), Jerman (Greitemeyer, 2009), dan China (To, 2013) yang melaporkan bahwa perempuan dewasa lajang mendapatkan stereotip dan stigma karena status kelajangannya.

Salah satu partisipan, Nisa, melaporkan bahwa orang-orang di sekitarnya menganggap dirinya terlalu menutup diri sehingga ia belum menikah sampai saat ini. Penemuan ini sejalan dengan penelitian Indriana dkk. (2007) yang melaporkan bahwa perempuan dewasa lajang di Jawa yang menjadi partisipan mereka dianggap menutup diri dari orang lain (eksklusif). Nisa juga pernah mendengar ia disebut sebagai perawan tua yang tidak laku. Partisipan lain, Eki, juga pernah mendengar ia diperbincangkan sebagai perempuan yang tidak laku karena belum menikah. Noviana \& Suci (2010) juga menggambarkan sering munculnya stigma masyarakat terhadap perempuan lajang di Indonesia dengan julukan 'perawan tua' atau 'tidak laku' terhadap mereka. Perempuan lajang di China juga mendapatkan julukan serupa, yaitu sheng nu (leftover women) yang berarti 'perempuan sisa' (To, 2013). Bahkan karena status lajangnya, Eki pernah dituduh akan merebut suami orang oleh tetangganya. Seperti halnya partisipan lain, Rina melihat masyarakat memandang negatif perempuan dewasa lajang sebagai "tidak laku". Status mereka yang tetap lajang sering dipandang sebagai akibat "jual mahal" hingga belum mendapatkan pasangan.

Pengalaman mendapatkan stigma dari masyarakat telah menimbulkan dampak pada kondisi psikologis para partisipan. Para partisipan dalam penelitian ini melaporkan mereka merasa tertekan dengan tuntutan dan desakan keluarga dan teman-teman mereka agar partisipan segera menikah. Elisabeth menggambarkan pertanyaan-pertanyaan seputar kapan menikah dari lingkungan sekitarnya sebagai "teror" yang mengganggu. Marina dan Rina merasakan bagaimana keluarganya menuntut mereka agar segera memiliki pasangan. Hasil penelitian ini juga sejalan dengan penelitian Indriana dkk., (2007) yang menunjukkan bahwa tuntutan dari keluarga dan masyarakat seperti "kapan menikah?" kerap ditujukan kepada perempuan yang masih lajang.

Bahkan keluarga Rina mengaku malu jika anaknya tidak segera menikah. Rina pun menyadari tuntutan keluarganya tersebut. Hasil penelitian ini juga sejalan dengan hasil penelitian Noviana \& Suci (2010) terhadap perempuan karir belum menikah di Jakarta yang mengalami konflik dalam diri mereka akibat mendapat tuntutan dari orangtua untuk segera menikah. Keempat partisipan dalam penelitian tersebut seluruhnya menilai tuntutan orangtuanya untuk menikah adalah kewajiban yang harus dipenuhi. Terlebih lagi pada perempuan Jawa yang telah dewasa, menikah adalah tuntutan budaya yang sangat penting. Orangtua memiliki kewajiban untuk menikahkan puterinya, dan menjadi tugas puterinya untuk membantu orangtuanya memenuhi tugas tersebut (Hapsari dkk, 2007).

Hadirnya stigma yang mempengaruhi kondisi psikologis partisipan kemudian mendorong keinginan partisipan untuk menjadi normal sesuai harapan masyarakat, yakni menikah. Akibatnya, kadangkala di saat-saat tertentu para partisipan merasakan kesepian. Menurut Baron \& Byrne (2003) permasalahan kesepian merupakan fenomena umum yang terjadi di seluruh dunia yang merupakan suatu keadaan emosi dan kognitif yang disebabkan tidak tercapainya uapaya menjalin hubungan yang akrab dengan orang lain. Marina yang merupakan salah satu partisipan pada penelitian ini mengungkapkan bahwa menjadi perempuan lajang membuat 
dirinya merasakan kesepian karena tidak ada yang menemani, mengantarkannya, dan memberinya perhatian.

Jika ditinjau dari sudut pandang teori Erikson dalam tahap perkembangan psikososialnya yang keenam, yaitu intimacy versus isolation, apabila orang dewasa awal tidak dapat menjalin komitmen pribadi dengan orang lain, maka mereka dapat menjadi terisolasi (Feldman, 2009). Isolasi adalah ketidakmampuan untuk bekerja sama dengan orang lain melalui kepercayaan, pengorbanan, dan komitmen dalam suatu hubungan intim (Feldman, 2009). Erikson menambahkan bahwa wanita dewasa yang belum menikah akan merasa kesepian karena teman-teman lama méreka sudah berpencar dan sibuk dengan urusan keluarga masing-masing (Hurlock, 1980). Elisabeth merasakan ada saatsaat tertentu dirinya ingin sekali menikah. Ia tidak bisa menghilangkan keinginannya untuk menikah walaupun telah berusaha. Menurut Hurlock (1980), pada dasarnya memang tidak semua perempuan yang tidak menikah bermaksud untuk terus menjadi single.

Rasa iri pun tidak dapat dihindarkan oleh Marina, saat ia melihat ada perempuan yang masih muda sudah menikah dan memiliki anak. Rasa iri ingin memiliki pasangan juga muncul saat ada sepasang suami istri menunjukan kemesraan didepan pasrtisipan. Eki melihat seorang suami yang memberikan perhatian kepada sang istri saat istrinya mengeluh sakit. Hal yang sama dirasakan oleh Elisabeth, ia merasa kesulitan saat dirinya membutuhkan bantuan pria untuk menemaninya pergi keluar kota dimalam hari. Namun, perasaan membutuhkan kehadiran pasangan itu hanya muncul pada momen-momen tertentu.

Pengalaman mendapatlan stigma dan dampak psikologis yang ditimbulkannnya mendorong para partisipan untuk melakukan upaya untuk menghadapi stigma dan tekanan psikologis tersebut. Berdasarkan model ancaman identitas yang ditimbulkan dari stigma menurut Major dan O'Brien (2004) ancaman identitas akan ditanggapi dengan dua cara yakni, cara vokasional dan cara nonvokasional, cara vokasional adalah cara yang melibatkan usaha untuk menyelesaikan, sedangkan cara non vokasional yakni tidak melibatkan usaha untuk menyelesaikan. Penelitian ini menemukan bahwa para partisipan menggunakan tiga cara menghadapi stigma, yaitu: pertama, memaknai kembali status lajang secara lebih positif, menghindari stuasi yang mengundang stigma, dan menyerahkan diri pada takdir Tuhan. Dalam perspektif teori Major \& O'Brien (2004), tiga strategi tersebut dapat digolongkan sebagai cara nonvokasional karena tidak melibatkan upaya secara langsung dalam melawan atau menghilangkan stigma.

Para partisipan penelitian ini menyadari bahwa mereka berbeda dari perempuan pada umumnya yang telah menikah. Perbedaan tersebut tidak membuat mereka merasa lebih rendah dalam segala hal sebagai perempuan. Mereka masih memiliki hal-hal tertentu yang dapat diunggulkan selain masalah pernikahan. Para partisipan penelitian ini berupaya memaknai kembali status lajang mereka sebagai peluang mengalami kebebasan (freedom) dan kemandirian (independence). Nisa, Marina dan Ira merasakan kebebasan berupa bebas beristirahat sepulang kerja tanpa harus terbebani pekerjaan rumah tangga yang berantakan, bebas menginginkan sesuatu sesuai kehendaknya sendiri, dan bebas melakukan apapun tanpa perlu meminta persetujuan suami. Elisabeth juga secara jelas memaknai status lajangnya sebagai kemandirian yang membuatnya bangga sebagai perempuan. Hasil penelitian ini sejalan dengan penelitian Kumalasari (2007) terhadap 10 perempuan karir lajang kelas menengah berusia 30-50 tahun di Yogyakarta yang juga mengungkapkan bahwa mereka memaknai kelajangan sebagai kebebasan dan kemandirian. 
Memperhatikan dampak psikologis akibat stigma terhadap status lajang seperti rasa tertekan, kesepian, dan ketidaknyamanan, pemaknaan kembali status lajang sebagai kebebasan dan kemandirin pada para partisipan penelitian ini membuat status lajang mereka tampak menjadi dilematis. Posisi dilematis status lajang ini sesungguhnya tidak aneh. Reynolds \& Wetherell (2003) mereviu banyak penelitian tentang status identitas perempuan lajang dan menyimpulkan bahwa kelajangan (singleness) adalah sebuah kategori sosial yang "bermasalah" bahkan bagi mereka yang mendiami posisi tersebut. Perempuan lajang menghadapi beberapa dilema menyikapi posisi lajangnya. Di satu sisi mereka memandang kelajangan (singleness) sebagai kebebasan, kemandirian, atau prestasi. Di sisi lain, mereka memaknainya sebagai status yang membuat mereka tertekan, kesepian, dan ingin segera menuntaskannya (mencari pasangan).

Cara lain untuk menghadapi stigma adalah dengan menghindari situasi yang mengundang munculnya stigma. Pengalaman mendapatkan stigma telah memunculkan kekhawatiran para partisipan akan mengalami hal serupa di masa datang. Berbagai stereotip negatif yang disematkan pada status lajang telah menimbulkan ancaman terhadap identitas para partisipan sebagai lajang yang brujung pada timbulnya kekhawatiran individu tentang diri mereka sendiri (Derks, Inzlicht, \& Kang, 2008). Marina membatasi diri dan menjaga jarak dengan teman-temannya yang terlalu banyak ikut campur dalam urusan pribadinya terkait status lajangnya. Nisa dengan sengaja akan menolak menghadiri undangan pernikahan jika tidak ada yang menemani karena dia telah menduga akan mendapatkan pertanyaan-pertanyaan mengganggu seputar status lajangnya. Elisabeth pun enggan datang ke acara reuni teman sekolahnya karena ia tidak ingin diserbu dengan pertanyaanpertanyaan seputar status perkawinannya.
Elisabeth bahkan menyebut berondongan pertanyaan dari orang-orang di sekitarnya sebagai "teror" yang sangat mengganggunya.

Cara terakhir yang dilakukan para partisipan untuk mengatasi stigma terhadap mereka adalah dengan menyerahkan nasibnya pada Tuhan. Nisa menjelaskan kepada orangorang yang mendesaknya untuk segera menikah bahwa kelahiran, kematian dan Jodoh adalah rahasia Tuhan. Dengan memasrahkan diri pada takdir, Rina berusaha menjawab pandangan negatif orang bahwa yang menjadi penyebab kelajangannya bukanlah sifat dirinya, tapi karena kehendak Tuhan. Kepasrahan pada Tuhan ini juga membantu Ira untuk bersiap gagal apabila upayanya untuk mendapat pasangan hidup tidak berhasil. Wawasan dari para partisipan ini menjukkan bahwa mereka memiliki kecenderungan locus of control eksternal. Baron \& Byrne (2005) menyatakan bahwa orang yang memiliki locus of control eksternal akan memandang situasi atau kejadian yang mereka alami sebagai akibat dari pengaruh faktor luar, bukan karena faktor internal dirinya. Sebagian partisipan berkeyakinan bahwa sebagai perempuan mereka tetap menginginkan berkeluarga. Namun sebagian besar dari partisipan pesimis akan hal itu menimbang usia mereka yang tidak lagi muda. Tekanan masyarakat dan stigma yang mereka alami turut memperkuat harapan mereka untuk menikah. Namun, jika harapannya itu tak terkabul, mereka tidak ingin orang di sekitarnya menyalahkan mereka. Dengan menyerahkan urusan jodoh di tangan Tuhan, beban mereka menjadi ringan.

\section{SIMPULAN}

Berdasarkan hasil dan pembahasan di atas, dapat disimpulkan bahwa mendiami posisi sebagai perempuan dewasa lajang bagi para partisipan penelitian ini telah mendatangkan stigma. Pengalaman terkait 
stigma terhadap perempuan dewasa lajang yang dihadapi para partisipan penelitian ini adalah julukan sebagai "perawan tua", "tidak laku", dan "sudah lewat masanya" yang mereka dengar secara langsung maupun tidak langsung. Pengalaman stigma juga muncul terkait anggapan orang-orang di sekitar para partisipan bahwa mereka tetap melajang karena ada yang salah dalam kepribadian mereka, di antaranya adalah sifat tertutup atau introvert. Pengalaman mendapatkan stigma ini telah berdampak pada kondisi psikologis para partisipan, di antaranya adalah perasaan tertekan karena dibombardir dengan pertanyaan-pertanyaan dan desakan untuk segera menikah. Para partisipan juga merasakan ketidaknyamanannya ketika menghadiri situasi-situasi yang bisa memunculkan stigma seperti resepsi pernikahan, ulang tahun dan reuni. Posisi sebagai perempuan dengan status lajang yang berbeda dari kebanyakan perempuan seusianya yang telah menikah juga menyebabkan sebagian partisipan penelitan ini mendambakan pernikahan. Para partisipan merasakan kesepian pada momen-momen tertentu kehidupan mereka dan mengharapkan hadirnya pasangan hidup.

Pengalaman stigma dan dampak psikologis tidak menyenangkan yang dialami membuat partisipan mencari cara untuk mengatasinya. Tiga strategi untuk mengatasi stigma dan tekanan psikologis akibat stigma digunakan oleh para partisipan penelitian ini, yaitu: pertama, memaknai kembali status lajang secara positif. Status lajang dimaknai sebagai peluang mengalami kebebasan dan bukti kemandirian. Cara kedua adalah dengan menghindari situasi yang mengundang stigma seperti tidak menghadiri undangan pernikahan, reuni, atau acara ulang tahun teman. Para partisipan sudah mengantisipasi bahwa kehadiran mereka akan mendatangkan perhatian berlebihan yang mengganggu. Cara terakhir untuk mengatsi stigma dan tekanan psikologis akibat stigma adalah dengan menyerahkan nasib pada takdir Tuhan. Para partisipan ingin menegaskan bahwa status lajang yang mereka emban bukan sepenuhnya tanggungjawab mereka. Mereka hanya menjalaninya sebagai takdir yang ditentukan Tuhan. Jika Tuhan menginginkan mereka menikah, maka jodoh akan datang. Sebaliknya, jika tidak ada jodoh, maka mereka meyakini hidup lajang adalah ketentuan Tuhan bagi mereka. Dengan keyakinan itu, para partisipan penelitian ini merasa lebih ringan menanggapi berbagai pertanyaan menggganggu dan stigma negatif terkait dengan status lajang mereka.

\section{DAFTAR PUSTAKA}

Baron, R. A., \& Byrne, D. (2003). Psikologi Sosial (Jilid $1 \&$ 2). (edisi Terjemahan). Jakarta: Erlangga.

Burke, P. J., \& Stets, J. E. (2000). Identity Theory and Social Identity Theory. Social Psychology Quarterly, 63(3), 224-237.

Byrne, A., \& Carr, D. (2005). Caught in the cultural lag: The stigma of singlehood. Psychological Inquiry, 16, 84-141.

Conley, T. D., \& Collins, B. E. (2002). Gender, relationship status, and stereotyping about sexual risk. Personality and Social
Psychology Bulletin, 28, 1483-1494.

DePaulo, B. (2008, November $\left.1^{\text {st }}\right)$. Living Single Longer: It's a Global Phenomenon. Psychology Today. Diakses dari: http://www.psychologytoday.com/blog/liv ing-single/200811/living-single-longer-itsglobal-phenomenon. pada 2 juli 2013.

DePaulo, B. M., \& Morris, W. L. (2005). Singles in society and in science. Psychological Inquiry, 16,57-83.

DePaulo, B. M., \& Morris, W. L. (2006). The unrecognized stereotyping and discrimination 
against singles. Current Directions in Psychological Science, 15, 251-254.

Derks, B., Inzlicht, M., \& Kang, S. (2008). The Neuroscience of Stigma and Stereotype Threat. Group Processes \& Intergroup Relations, 163-181.

Elliot, R., Fischer, C.T., dan Rennie, D.L. (1999). Evolving guidelines for publication of qualitative research studies in psychology and related. British Journal of Clinical Psychology. 38, 215-229

Emzir. (2010). Metodelogi Penelitian Kualitatif, Analisis Data. Jakarta: Raja Grafindo Persada.

Etaugh, C., \& Birdoes, L. N. (1991). Effects of age, sex, and marital status on person perception. Perceptual and Motor Skills, 72, 491-497.

Feldman, P. O. (2009). Human Development, Perkembangan Manusia. Jakarta: Salemba Humanika.

Goffman, E. (1963). Stigma: Notes on the management of spoiled identity. Englewood Cliffs, NJ: Prentice Hall.

Greitemeyer, T. (2009). Stereotypes of singles: Are singles what we think? European Journal of Social Psychology, 39, 368-383

Hapsari, P., Nisfiannoor, M., \& Murmanks, A. W. (2007). Konflik Perempuan Jawa yang Masih Melajang di Masa Dewasa Madya. Jurnal Arkhe, 12 (1), 41-56.

Hurlock, E. B. (1980). Psikologi Perkembangan: Suatu Pendekatan Sepanjang Rentang Kehidupan. Jakarta: Erlangga.

Indriana, Y., Indrawati, E. S., \& Ayuaningsih, A. (2007). Persepsi Perempuan Karir Lajang Tentang Pasangan Hidup: Studi Kualittatif Fenomenologis di Semarang. Jurnal Arkhe, 12 (2), 153-167.

Korf, L., \& Malan, J. (2002). Threat to Ethnic Identity: The Experience of White Afrikaans-Speaking Participants in Postapartheid South Africa. Journal of Social Psychology, 142 (2), 149-169.

Kumalasari, D. (2007). Single Professional Women Sebagai Fenomena Gaya Hidup
Baru di Masyarakat Yogyakarta (Studi Kasus: Kabupaten Sleman). (Laporan Penelitian). Yogyakarta: Universitas Negeri Yogyakarta. Diakses dari: http://staff.uny.ac.id/sites/ default/files/penelitian/dr.\%20dyah\%20ku $\mathrm{m}$ a 1 a $\mathrm{s}$ a $\mathrm{r}$ i , \% $20 \mathrm{~m}$. p d . / single $\% 20$ professional $\%$ 20women $\% 20 \mathrm{seb}$ a ga i $\% 20 \mathrm{fen}$ omena $\%$ 20gaya\%20hidup\%20baru\%20di\%20masy arakat\%20yogyakarta.pdf. pada 2 juli 2013.

Major, B. \& O'Brien, L.T. (2005) The Social Psychology of Stigma. Annual Review of Psychology, 56, 393-421.

Markus, H. R., \& Kitayama, S. (1991). Culture and the self: Implications for cognition, emotion, and motivation. Psychological Review, 98 (2), 224-253.

Matsumoto, D. (2004). Pengantar Psikologi Lintas Budaya (edisi terjemahan). Yogyakarta: Pustaka Pelajar

Moleong, L. J. (2012). Metodologi Penelitian Kualitatif. Bandung: Remaja Rosdakarya.

Morris, W.L., Sinclair, S., \& DePaulo, B. M. (2007). No shelter for Singles: The perceived legitimacy of marital status discrimination. Group Processes Intergroup Relations, 10, 457-470

Noviana, C. L. D., \& Suci, E. S. T. (2010). Konflik Intrapersonal Wanita Lajang Terhadap Tuntutan Orangtua Untuk Menikah. Jurnal Psikologi Indonesia, 7 (1), 9-16.

Reynolds, Jill \& Wetherell, Margaret (2003). The discursive climate of singleness: the consequences for women's negotiation of a single identity. Feminism \& Psychology, 13 (4), 489-510.

Reynolds, J. (2002) 'Constructing the single woman in therapy', The Journal of Critical Psychology, Counselling and Therapy, 2 (1): 20-31.

Smith, J. A. \& Osborn, M. (2009). Analisis Fenomenologi Interpretatif. Dalam J. A. Smith.(ed.). Psikologi Kualitatif: Panduan Praktis Metode Riset. (Edisi Terjemahan). Pustaka Pelajar: Yogyakarta. 
Tajfel, H., \& Turner, J. (1979). An integrative theory of intergroup conflict. In W. Astin \& S. Worchel (Eds.). The social psychology of intergroup relations (pp. 33-47). California: Brooks/Cole.

To, S. (2013). Understanding Sheng $\mathrm{Nu}$ ("Leftover Women"): the Phenomenon of
Late Marriage among Chinese Professional Women. Symbolic Interaction, 36 (1), 1-20. Doi: 10.1002/symb.46.

Walton, G. M., \& Cohen, G. L. (2007). A Question of Belonging : Race Social Fit, and Achievement. Journal of Personality and Social Psychology, 92(1). 82-96. 